\title{
Therapeutic efficacy of an oral nucleoside analog of remdesivir against SARS-CoV-2 pathogenesis in mice.
}

Alexandra Schäfer ${ }^{1,4}$, David R. Martinez ${ }^{1,4}$, John J. Won ${ }^{1}$, Fernando R. Moreira ${ }^{1}$, Ariane J. Brown ${ }^{1}$, Kendra L. Gully ${ }^{1}$, Rao Kalla ${ }^{2}$, Kwon Chun ${ }^{2}$, Venice Du Pont ${ }^{2}$, Darius Babusis ${ }^{2}$, Jennifer Tang ${ }^{2}$, Eisuke Murakami ${ }^{2}$, Raju Subramanian ${ }^{2}$, Kimberly T Barrett ${ }^{2}$, Blake J. Bleier ${ }^{2}$, Roy Bannister ${ }^{2}$, Joy Y. Feng ${ }^{2}$, John P. Bilello ${ }^{2}$, Tomas Cihlar ${ }^{2}$, Richard L. Mackman ${ }^{2}$, Stephanie A. Montgomery ${ }^{3}$, Ralph S. Baric ${ }^{1}$, Timothy P. Sheahan ${ }^{1, *}$

${ }^{1}$ Department of Epidemiology, University of North Carolina at Chapel Hill, Chapel Hill, NC, 11 USA,

${ }^{2}$ Gilead Sciences, Inc, Foster City, CA, USA,

${ }^{3}$ Department of Pathology and Laboratory Medicine, University of North Carolina School of Medicine, Chapel Hill, NC, USA,

${ }^{4}$ These authors contributed equally to this manuscript.

* Timothy P. Sheahan. sheahan@email.unc.edu

\section{Abstract}

The COVID-19 pandemic remains uncontrolled despite the rapid rollout of safe and 
35 The dose-proportional pharmacokinetic profile observed after oral administration of GS-621763

36 translated to dose-dependent antiviral activity in mice infected with SARS-CoV-2. Therapeutic

37 GS-621763 significantly reduced viral load, lung pathology, and improved pulmonary function

38 in COVID-19 mouse model. A direct comparison of GS-621763 with molnupiravir, an oral

39 nucleoside analog antiviral currently in human clinical trial, proved both drugs to be similarly

40 efficacious. These data demonstrate that therapy with oral prodrugs of remdesivir can

41 significantly improve outcomes in SARS-CoV-2 infected mice. Thus, GS-621763 supports the

42 exploration of GS-441524 oral prodrugs for the treatment of COVID-19 in humans.

Introduction

SARS-CoV-2 emerged in December 2019 and has caused 223 million infections and 4.6

47 vaccines, vaccination rates have lagged in the United States (U.S.) due to vaccine hesitancy and

48 public mistrust thus delaying the generation of herd immunity required to significantly diminish

49 community spread. In addition, outside of the U.S., many countries do not have equitable access

50 to vaccines and/or have been slow to vaccinate (4-7). This collective constellation of events is

51 fueling the generation of viral variants that are increasingly transmissible and are ever evolving

52 to escape human immunity. Therefore, there is an immediate unmet need for oral antivirals that

53 can be rapidly disseminated to treat COVID-19 cases in the unvaccinated, the

54 immunocompromised and in vaccine breakthrough cases. Next-generation oral coronavirus

$55(\mathrm{CoV})$ antivirals, if widely disseminated and given early in infection, could curtail the duration of

56 disease, reduce long-term sequelae of COVID-19, minimize household transmissions, and lessen

57 hospitalizations, thus having a broad impact on public health. 
There are multiple direct-acting antiviral (DAA) therapies in use to treat COVID-19 (8-

61 efficacy for treating active COVID-19 cases in outpatients (Regeneron outpatient studies) but

62 currently, all mAbs must be administered via injection, limiting their use to those with ready

63 access to healthcare $(13,14)$. In addition, several SARS-CoV-2 variants of concern (VOCs) have

64 evolved that are resistant to first-line mAb therapies $(15,16)$. Currently, RDV is the only FDA-

65 approved small-molecule direct-acting antiviral to treat COVID-19, but there are several other

66 DAAs currently in human clinical trials including nucleoside analogs molnupiravir (MPV,

67 EIDD-2801) and AT-527, as well as MPro inhibitor PF-07321332 (17-25). Unlike mAbs which

68 specifically target the virion surface exposed spike protein of SARS-CoV-2, nucleoside analog

69 drugs target a highly conserved viral enzyme among CoV, the RNA-dependent RNA polymerase

70 (RdRp) nsp12, rendering them broadly active against multiple emerging, endemic and enzootic

$71 \mathrm{CoV}$. Moreover, due to its high degree of conservation among CoV, the RdRp likely does not

72 have the same capacity for mutational change as spike, which may translate into RdRp having a

73 higher barrier to resistance (18-20). Despite demonstrated therapeutic efficacy of RDV against

74 SARS-CoV-2 in animal models $(17,23,26)$ and in human clinical trials $(8)$, the requirement of

75 intravenous administration has limited its widespread use during this pandemic. The orally

76 bioavailable nucleoside prodrug GS-621763, is designed for optimal delivery of the parent

77 nucleoside GS-441524 into systemic circulation, which is then metabolized inside cells into the

78 same active nucleoside triphosphate formed by RDV (27). Here, we detail the in vitro antiviral

79 activity in various cell models and in vivo therapeutic efficacy of oral GS-621763 in a mouse

80 model of SARS-CoV-2 pathogenesis. 
Version 9.4

Results

GS-621763 has antiviral activity against SARS-CoV-2 in cell lines and human primary cell cultures. monophosphoramidate prodrug RDV (GS-5734, Fig. 1B), and triester prodrug GS-621763 (Fig. 1C). All three molecules are metabolized to the same active nucleotide triphosphate in cells, but through different activation pathways. GS-621763 is rapidly metabolized during oral absorption to GS-441524, then intracellularly converted by cellular kinases to the analog monophosphate metabolite before further metabolism to the active nucleoside triphosphate. In contrast, the intact

91 phosphoramidate prodrug, RDV, is broken down inside cells directly to the same monophosphate

92 metabolite, effectively bypassing the rate-limiting first phosphorylation step of GS-441524 (27).

93 To determine if GS-621763 could inhibit replication of SARS-CoV-2 in cellular assays, we first

94 evaluated its antiviral activity against a SARS-CoV-2 reporter virus expressing nanoluciferase

95 (SARS-CoV-2 nLUC) in A549-hACE2 cells stably expressing the human entry receptor

96 angiotensin-converting enzyme 2 (ACE2) (28). With GS-621763, we observed a dose-dependent

97 antiviral effect on SARS-CoV-2 nLUC replication with an average half-maximum effective

98 concentration $\left(\mathrm{EC}_{50}\right)$ of $2.8 \mu \mathrm{M}$ (Fig. 1D, Fig.1H, and Supplementary Figure 1A). In the same

99 assay, we measured $\mathrm{EC}_{50}$ values for the control compound $\mathrm{RDV}$ of $0.28 \mu \mathrm{M}$, similar to those

100 reported previously in these cells and reflective of the enhanced ability of the phosphoramidate

101 prodrug to rapidly and efficiently generate active triphosphate by bypassing the slower initial

102 phosphorylation step (Fig. 1D, Fig. 1H, Supplementary Figure 1A) (29). As was observed in

103 other cell systems, the parental nucleoside, GS-441524, was less potent $\left(\mathrm{EC}_{50}=3.3 \mu \mathrm{M}\right)$ than 
104 RDV in our assay and was similar in potency to GS-621763. This suggests that the tri-isobutyryl esters of GS-621763 are efficiently cleaved in the assay to release GS-441524 (Fig. 1D, Fig. 1H,

106 Supplementary Figure 1A). Importantly, we did not observe any measurable cytotoxicity of any

107 of the inhibitors in A549-hACE2 cells at concentrations up to $10 \mu \mathrm{M}$ (Figure 1F, Supplementary

108 Figure 1B). Human primary airway epithelial (HAE) cell cultures model the cellular complexity

109 and architecture of the human conducting airway and are often used to determine if drugs are

110 transported and metabolized in the cells targeted by emerging CoV in vivo (18). In HAE cells

111 infected with WT SARS-CoV-2 (28) and treated with GS-621763, we observed a dose-

112 dependent and significant reduction in infectious virus production as compared to DMSO-

113 vehicle treated cultures (Fig. 1F). In similarly infected, control compound (i.e. RDV or GS-

114 441524) treated cultures, a significant and dose-dependent reduction in viral titers was also

115 observed (Fig. 1F). GS-621763, RDV, and GS-441524 inhibited reporter SARS-CoV-2

116 expressing Firefly luciferase (SARS-CoV-2 Fluc) replication in normal human bronchial

117 epithelial (NHBE) cultures with $\mathrm{EC}_{50}$ values of $0.125,0.0371$, and $2.454 \mu \mathrm{M}$, respectively (Fig.

118 1G, Fig. 1H). All together, these data show that GS-621763 is transported, metabolized and

119 potently antiviral human primary cell systems that model the tissues targeted by SARS-CoV-2 in 120 humans.

Dose-dependent therapeutic efficacy of GS-621763 in mouse models of COVID-19 disease.

We have previously performed multiple studies describing the therapeutic efficacy of

124 subcutaneously administered RDV in mice (Ces $\left.1 c^{-/-} \mathrm{C} 57 \mathrm{BL} / 6 \mathrm{~J}\right)$ genetically deleted for a secreted

125 plasma carboxylesterase 1c (Ceslc) absent in humans but dramatically reduces drug half-life in

126 wild-type mice $(17-19,26,30)$. 
However, the prodrug GS-621763 is designed to be rapidly cleaved pre-systemically in vivo to release GS-441524 into circulation, with no or very minimal intact ester observed in

129 plasma. Therefore, GS-621763 can be studied in wild-type mice where it should also be rapidly

130 converted to parent GS-441524. Plasma pharmacokinetics following a single oral administration

131 of GS-621763 at either 5 or $20 \mathrm{mg} / \mathrm{kg}$ were first determined in uninfected BALB/c mice (Fig.

132 2A). Doses were selected to provide high plasma exposures of GS-441524 that would support

133 active triphosphate formation in the lung and to confirm pharmacokinetic dose proportionality

134 needed to project exposures in efficacy studies. Previous studies had shown that parent

135 nucleoside was at least 10 -fold less efficient at generating lung triphosphate than RDV, on a

136 molar basis, thus requiring higher plasma exposures of parental GS-441524 to account for the

137 reduced metabolic efficiency (27). No exposure of intact ester prodrug, within the limit of

138 detection, was observed in mice. GS-441524 was both rapidly absorbed and then cleared from

139 systemic circulation, exhibiting a short plasma half-life of approximately $1 \mathrm{hr}$. Dose

140 proportional increases in both maximal plasma concentrations $\left(\mathrm{C}_{\max }\right)$ and exposures $\left(\mathrm{AUC}_{0-24 \mathrm{~h}}\right)$

141 at the two doses were observed (Fig. 2A).

142 To better understand the pharmacokinetic and pharmacodynamic relationship for GS-

143621763 , we performed a series of dose-finding studies in BALB/c mice infected with mouse-

144 adapted SARS-CoV-2 (SARS-CoV-2 MA10) (30). In young adult BALB/c mice infected with

$14510^{4}$ plaque forming units (PFU) SARS-CoV-2 MA10, virus replicates to high titers in the

146 respiratory tract, mice lose $15-20 \%$ of their body weight by 4 days post-infection (dpi), and acute

147 lung injury/loss of pulmonary function is typically observed after virus replication peaks on 2 dpi

148 (30). We first defined the minimum dosage sufficient for maximal therapeutic efficacy in

$149 \mathrm{BALB} / \mathrm{c}$ mice initiating twice daily (i.e. bis in die, BID) oral treatment with either vehicle control 
150 or $3 \mathrm{mg} / \mathrm{kg}, 10 \mathrm{mg} / \mathrm{kg}$, or $30 \mathrm{mg} / \mathrm{kg} \mathrm{GS}-621763$ beginning 8 hours post infection (hpi) with $10^{4}$

151 PFU SARS-CoV-2 MA10 (Fig. 2B). Unlike vehicle or 3 mg/kg GS-621763 treated animals,

152 mice receiving either 10 or $30 \mathrm{mg} / \mathrm{kg}$ GS-621763 were completely protected from weight loss

153 thus demonstrating that early oral antiviral therapy can prevent the progression of disease (Fig.

154 2B). Congruent with the weight loss phenotype, both 10 and $30 \mathrm{mg} / \mathrm{kg} \mathrm{GS}-621763$ treated

155 animals had significantly reduced viral lung titers as compared to both the vehicle and $3 \mathrm{mg} / \mathrm{kg}$

156 treated groups (Fig. 2C). To monitor the effect of drug treatment on pulmonary function, we

157 performed daily whole-body plethysmography (WBP) with a subset of mice from each group

158 ( $\mathrm{N}=4$ per treatment group). As shown with the WBP metric PenH, whose elevation is associated

159 with airway resistance or obstruction (18), we observed a drug dose-dependent reduction in

160 PenH with the maximal effect seen in the $30 \mathrm{mg} / \mathrm{kg}$ GS-621763 dose group which was

161 completely protected from the loss of pulmonary function observed in the other treatment groups

162 and vehicle (Fig. 2D). Mice treated with 3 and $10 \mathrm{mg} / \mathrm{kg}$ GS-621763 had impaired lung function

163 at days 2 and 3 post infection, but lung function returned to baseline by 4 dpi for all GS-621763

164 treated animals (Fig. 2D). Consistent with weight loss, virus titer, and pulmonary function data,

165 mice treated with 10 or $30 \mathrm{mg} / \mathrm{kg}$ had significantly reduced lung congestion, a gross pathologic

166 feature characteristic of severe lung damage (Fig. 2E). We then scored lung tissue sections for

167 the histologic features of acute lung injury (ALI) using two complementary semiquantitative

168 tools. First, using an ALI scoring tool created by the American Thoracic Society (ATS), we

169 blindly evaluated three diseased fields per lung section for several features of ALI including

170 alveolar septal thickening, neutrophils in the interstitium and in air spaces, proteinaceous debris

171 in airspaces, and the presence of hyaline membranes. Only mice treated with $30 \mathrm{mg} / \mathrm{kg} \mathrm{had}$

172 significantly reduced ALI scores (Fig. 2F). Second, we used a complementary tool measuring 
173 the pathologic hallmark of ALI, diffuse alveolar damage (DAD). Mice in all treated groups

174 showed reduced DAD scores, but only mice receiving $30 \mathrm{mg} / \mathrm{kg}$ had significantly decreased

175 DAD in their lungs (Fig. 2G). Together, these data demonstrate that the oral delivery of the

176 nucleoside analog GS-621763 can significantly diminish SARS-CoV-2 virus replication and

177 associated pulmonary disease in a dose-dependent manner.

178

179

Extended therapeutic protection against COVID-19 disease by GS-621763 in mice

To determine if the potent therapeutic efficacy of GS-621763 observed with early

181 intervention ( $8 \mathrm{hr}$ after infection) would extend to later times post infection, we designed a

182 therapeutic efficacy study with six arms where we varied both time of oral therapy initiation and

183 dose level in BALB/c mice infected with SARS-CoV-2 MA10 (Fig.3). As done previously, a

184 control group of animals received vehicle twice daily beginning at 12 hours post infection (hpi).

185 The next three arms of the study were dedicated to the $30 \mathrm{mg} / \mathrm{kg}$ GS- 621763 dose level, with two

186 of the three arms receiving twice daily dosing initiated at either the $12 \mathrm{hpi}$ (" $30 \mathrm{mg} / \mathrm{kg}$ BID 12

187 hr" group) or the $24 \mathrm{hpi}$ (“30 mg/kg BID $24 \mathrm{hr”} \mathrm{group).} \mathrm{The} \mathrm{third} 30 \mathrm{mg} / \mathrm{kg}$ arm was designed to

188 determine if dose frequency could be reduced to once daily (quaque die, QD) if initiated early at

$18912 \mathrm{hpi}$ (“30 mg/kg QD $12 \mathrm{hr”}$ group). In the last two arms, we wanted to evaluate if an increased

190 dose of $60 \mathrm{mg} / \mathrm{kg}$ given QD beginning at $12 \mathrm{hr}$ or $24 \mathrm{hr}$ (“60 mg/kg QD $12 \mathrm{hr}$ " and "60 mg/kg

191 QD 24 hr” groups) would improve outcomes over the $30 \mathrm{mg} / \mathrm{kg}$ groups. Initiation of $30 \mathrm{mg} / \mathrm{kg}$

192 BID therapy at either 12 or 24 hrs offered significant protection from weight loss (Fig. 3A),

193 extending the robust therapeutic phenotype observed for this dose level when initiated at very

194 early times (at $8 \mathrm{hr}$ ) (Fig 2). Interestingly, when we decreased the frequency of $30 \mathrm{mg} / \mathrm{kg}$

195 treatment initiated at $12 \mathrm{hr}$ to once daily (“30 mg/kg QD $12 \mathrm{hr”} \mathrm{group),} \mathrm{we} \mathrm{also} \mathrm{observed} \mathrm{a}$ 
196 significant prevention of body weight loss (Fig 3A), thus levels of drug when administered once

197 a day and begun early (at $12 \mathrm{hr}$ ) in the course of infection were sufficient to prevent disease

198 progression. Increasing the dose to $60 \mathrm{mg} / \mathrm{kg}$ QD initiated at either $12 \mathrm{hr}$ or $24 \mathrm{hr}$ offered similar

199 protection from weight loss observed with vehicle treatment as the $30 \mathrm{mg} / \mathrm{kg}$ groups (Fig. 3A).

As body weight loss is a crude marker of viral pathogenesis, we next measured multiple

201 virological, physiologic, and pathologic metrics of disease. First, we measured the levels of

202 infectious virus present in lung tissue on 4 dpi. Unlike vehicle-treated animals who harbored an

203 average titer of 5.6x10 4 PFU per lung lobe, all GS-621763 dose groups significantly reduced the

204 levels of infectious virus in lung tissue with the average titers of most groups falling below the

205 limit of detection (90 PFU). Interestingly, $30 \mathrm{mg} / \mathrm{kg}$ delivered QD had significantly elevated

206 viral lung titers (mean titer $=4 \times 10^{2} \mathrm{PFU}$ ) as compared to its BID counterpart (mean titer $=<90$

207 PFU). A similar trend among treatment groups was observed when measuring the levels of

208 SARS-CoV-2 subgenomic and genomic nucleocapsid (N) RNA in parallel lung tissues (Fig. 3C).

209 All $30 \mathrm{mg} / \mathrm{kg}$ groups significantly reduced levels of SARS-CoV-2 RNA in lung tissue as

210 compared to vehicle-treated animals. As observed for infectious titers, $30 \mathrm{mg} / \mathrm{kg}$ given QD daily

211 beginning at $12 \mathrm{hr}$ had elevated levels of $\mathrm{N}$ RNA as compared to $30 \mathrm{mg} / \mathrm{kg}$ given BID beginning

212 at $12 \mathrm{hr}$ suggesting that trough and/or daily exposure levels of drug with QD dosing are

213 insufficient to suppress replication similarly to BID dosing. Increasing the once-daily dose to 60

$214 \mathrm{mg} / \mathrm{kg}$ to raise the daily exposure and trough levels offered similar reductions in SARS-CoV-2 N

215 RNA as compared to $30 \mathrm{mg} / \mathrm{kg}$ BID when initiated at $12 \mathrm{hr}$, but the levels of viral RNA in the

216 higher dose $60 \mathrm{mg} / \mathrm{kg}$ group initiated at $24 \mathrm{hr}$ were not different than vehicle (Fig. 3C). Although

217 vehicle-treated animals exhibited significant loss of pulmonary function as measured by WBP,

218 this was largely prevented with GS-621763 therapy (Fig. 3D). All therapy groups initiated at 12 
219 hr were equally protected from loss of pulmonary function as measured by the PenH metric (Fig.

220 3D). Of all groups actively receiving GS-621763, animals in the $30 \mathrm{mg} / \mathrm{kg}$ BID $24 \mathrm{hr}$ group had

221 a measurable loss of lung function on 3 dpi which resolved by 4 dpi but this phenotype was not

222 extended to other groups. We then scored lung tissue sections for the histologic features of acute

223 lung injury and alveolar damage. Only $30 \mathrm{mg} / \mathrm{kg}$ BID initiated at $12 \mathrm{hr}$ significantly reduced ALI

224 scores as compared to those in vehicle-treated animals. In addition, the $30 \mathrm{mg} / \mathrm{kg}$ BID $12 \mathrm{hr}-$

225 group had significantly lower ALI scores as compared to the $60 \mathrm{mg} / \mathrm{kg}$ QD 24 hr-group (Figure

$2263 \mathrm{E})$. Only $30 \mathrm{mg} / \mathrm{kg}$ given twice a day at $12 \mathrm{hr}$ most dramatically reduced DAD scores but this

227 protection from lung pathology was lost if given once per day or if initiated at $24 \mathrm{hr}$ (Fig. 3G).

228 The high dose of $60 \mathrm{mg} / \mathrm{kg}$ QD when initiated at $12 \mathrm{hr}$ improved DAD scores as compared to

229 similarly treated animals that began treatment at $24 \mathrm{hr}$. Collectively, these data demonstrate that

230 GS-621763 therapy can improve both virologic and pathogenic metrics, but the degree of

231 improvement was dependent on time of initiation and dose frequency.

The therapeutic efficacy of GS-621763 is similar to molnupiravir (MPV, EIDD-2801)

MPV is an oral nucleoside analog prodrug antiviral currently in Phase 3 clinical trial to

235 treat COVID-19 with demonstrated antiviral efficacy in mice against several emerging CoV

236 including SARS-CoV, MERS-CoV, and SARS-CoV-2 (18, 19, 21, 22). Like GS-621763, MPV

237 is a prodrug which is metabolized in vivo into a parental nucleoside ( $\beta$-D-N4-hydroxycytidine,

238 NHC) in its metabolic progression towards the antiviral active triphosphate (20). To determine if

239 GS-621763 would provide similar protection as MPV, we then designed comparative therapeutic

240 efficacy studies in the mouse model of SARS-CoV-2 pathogenesis described above. Pre-efficacy

241 pharmacokinetic studies in BALB/c mice $(30 \mathrm{mg} / \mathrm{kg}$ or $100 \mathrm{mg} / \mathrm{kg})$ were performed with MPV 
and showed dose proportional increases in NHC plasma exposures (Supplemental Fig. 2).

243 Pharmacokinetic modeling then determined that a daily $120 \mathrm{mg} / \mathrm{kg}$ dose (given $60 \mathrm{mg} / \mathrm{kg}$ BID)

244 would result in exposures similar to that observed in humans receiving $800 \mathrm{mg}$ BID, a dose

245 being evaluated in a human clinical trial (22). The comparative efficacy study included a vehicle

246 group and 5 additional groups receiving two doses of MPV or GS-621763 per day 12 hrs apart

247 (BID). Three arms of the study began dosing at $12 \mathrm{hr}: 30 \mathrm{mg} / \mathrm{kg}$ GS-621763, $30 \mathrm{mg} / \mathrm{kg}$ MPV

$248(0.5 \times$ human equivalent dose $)$ or $60 \mathrm{mg} / \mathrm{kg}$ MPV $(1 \times$ human equivalent dose $)$. At $24 \mathrm{hr}$, we

249 began dosing of two additional groups: $60 \mathrm{mg} / \mathrm{kg}$ GS-621763 or $60 \mathrm{mg} / \mathrm{kg}$ MPV. While SARS-

250 CoV-2 MA10 infection caused rapid weight loss in vehicle control animals, all animals receiving

251 either GS-621763 or MPV beginning at either 12 or $24 \mathrm{hr}$ were protected from weight loss (Fig.

252 4A). Similarly, upon titration of lung tissues at 4 dpi for infectious virus by plaque assay,

253 vehicle-treated animals had expectedly high levels of infectious virus which was significantly

254 reduced in all treatment groups, independent of drug type or initiation time (Fig. 4B). When

255 treatment was initiated at $12 \mathrm{hr}$, a moderate yet significant elevation in infectious titers was

256 observed in the $30 \mathrm{mg} / \mathrm{kg}$ MPV group, inferior to either equivalently dosed GS-621763 animals

257 or those receiving the higher dose $(60 \mathrm{mg} / \mathrm{kg})$ of MPV (Fig. 4B). To understand the relationship

258 between levels of infectious virus and viral RNA in lung tissue, we performed qRT-PCR on total

259 RNA for SARS-CoV2 N RNA in parallel tissues utilized for plaque assay. The trend observed

260 with infectious virus is mirrored in the qRT-PCR data where all groups receiving antiviral

261 therapy had significantly reduced levels of viral RNA (Fig. 4C). In addition, animals receiving

$26230 \mathrm{mg} / \mathrm{kg}$ MPV $(0.5 \times$ human equivalent dose $)$ had a measurable increase in N RNA as compared

263 to equivalently dosed GS-621763 animals. Similar to weight loss data, vehicle-treated animals

264 had a significant loss of pulmonary function as measured by WBP on both 3 and 4 dpi which was 
265 prevented in all groups receiving antiviral treatment (Fig. 4D). We then blindly evaluated lung

266 tissue sections for the pathological manifestations of ALI and DAD using two complementary

267 histologic tools described above. Congruent with the above data, ALI scores in all antiviral

268 therapy groups were significantly reduced as compared to vehicle controls (Fig. 4E). In

269 agreement with ALI scores, the DAD histologic scores were similarly reduced in all antiviral

270 therapy treated groups as compared to those treated with vehicle (Fig. 4F). All together, these

271 data show that antiviral therapy with GS-621763 and MPV when initiated early or at the peak of

272 virus replication ( $24 \mathrm{hr}$ ) can both significantly diminish virus replication and improve disease

273 outcomes.

\section{Discussion}

276 Three novel human CoVs have emerged in the past 20 years, first with SARS-CoV in

277 2002-2003, MERS-CoV in 2012 and most recently, SARS-CoV-2 in 2019 (1, 2, 31). Vaccine

278 availability, vaccine hesitancy, and the ongoing evolution and emergence of VOCs are

279 collectively delaying the global control of pandemics and potential achievement of global herd

280 immunity and may prevent it altogether $(15,32-34)$. As such, there is an acute need for broad-

281 spectrum antivirals to treat COVID-19 in the unvaccinated as well as increasingly common

282 breakthrough infections in those vaccinated, driven by immune evading VOCs. In addition, due

283 to the emergence potential of the CoV family, we must also actively develop broadly acting

284 therapies effective the CoVs of today to prepare for those that may emerge in the future. Both

285 RDV and MPV are examples of nucleoside analogs with broad activity against genetically

286 diverse $\mathrm{CoV}$ (35). Here, we show that GS-621763, a prodrug that improves the oral delivery of 
parent nucleoside GS-441524, is yet another example of an orally bioavailable nucleoside analog prodrug that is effective against SARS-CoV-2.

Oral broadly acting antiviral therapies that target conserved viral proteins with a

290 diminished capacity for evolutionary change will maximize therapeutic utility against future

291 emerging CoV. SARS-CoV-2 has undergone a considerable amount of genetic evolution since

292 its emergence in 2019; each time a globally dominant SARS-CoV-2 VOC has emerged, it has

293 been replaced by a new VOC harboring more concerning characteristics like replicative capacity

294 or transmissibility (36). The majority of genetic changes have been localized to viral proteins

295 decorating the surface of the virus particle like the viral spike which has mutated to eradicate

296 epitopes targeted by early and promising monoclonal antiviral therapies (e.g. Eli Lily,

297 Regeneron) rendering them less active against newer VOCs (37). Approved antivirals like RDV,

298 those in clinical trials like MPV, AT-527, and PF-07321332 (Pfizer, oral protease inhibitor)

299 target highly conserved enzymes required for virus replication which likely have a diminished

300 capacity for change as compared to the spike protein (38). The widespread use of both RDV and

$301 \mathrm{mAb}$ therapies in the U.S. and globally has been limited by the necessity of delivery by

302 intravenous infusion which in turn requires access to qualified health care staff and facilities.

303 Thus, effective oral antiviral therapy or combination therapies which can be procured at a

304 pharmacy and self-administered by the patient would help facilitate wide-spread global access

305 and could have profound positive impacts on global public health.

In this study, we utilized a mouse adapted SARS-CoV-2 variant, SARS-CoV-2 MA10, in

307 wild-type BALB/c mice. $(17,30)$. Mice infected with this virus develop severe lung disease

308 reminiscent of that seen with severe COVID-19 including the development of ALI and

309 respiratory failure (30). It is important to note that the disease resulting from SARS-CoV-2 
310 MA10 infection in mice is compressed as compared to that observed in humans with virus titer

311 peaking in the mouse lung between $24-48$ hrs after infection, rapid loss of pulmonary function

312 beginning 2-3 dpi, rapid weight loss within the first 4 days of infection, lung pathology

313 consistent with ALI peaking 4-6 dpi and virus induced mortality within a week of infection. This

314 is markedly different than the COVID-19 in humans where virus titers peak in the upper airway

315 within the first week, but viral RNA shedding can be observed for as long as 24 days and

316 symptoms can take weeks to months to resolve (39-41). Because of this caveat associated with

317 our mouse model, the time in which to intervene with a direct acting antiviral and sufficiently

318 improve outcomes is curtailed in mice as compared to humans. Our recent study with RDV

319 exemplifies this where we found the degree of therapeutic benefit in mice infected with SARS-

320 CoV-2 MA10 was dependent on the time of initiation (17). Here, we show that oral

321 administration with GS-621763 prevents body weight loss, loss of pulmonary function, severe

322 lung pathology and virus replication when administered at 12 and 24 hrs after infection. While

323 we observed improvement in some metrics with RDV initiated at $24 \mathrm{hr}$ in our prior studies (17),

324 GS-621763 therapy initiated at a similar time comparatively improved all metrics assessed.

325 Thus, herein we provide proof-of-concept preclinical data that the orally bioavailable ester

326 analog of RDV GS-621763 can exert potent antiviral effects in vivo during an ongoing SARS-

327 CoV-2 infection. Lastly, we show that GS-621763 therapy provides similar levels of protection

328 from SARS-CoV-2 pathogenesis as MPV, an oral nucleoside analog prodrug effective against

329 SARS-CoV-2 in mice that is currently in human clinical trials. Future directions are focused on

330 extending these studies to evaluate the efficacy of combinations of antivirals in our models of

331 SARS-CoV-2 pathogenesis and in other models that can evaluate the blockade of transmission

332 such as hamster and ferret. 
In summary, we provide preclinical data demonstrating the in vitro antiviral activity and

334 in vivo therapeutic efficacy of an orally bioavailable nucleoside analog prodrug, GS-621763. The

335 data provided herein supports the future evaluation of orally bioavailable prodrugs of GS-441524

336 in humans with COVID-19. If safe and effective, this class of RdRp inhibitors could become part

337 of the arsenal of existing oral antivirals that are desperately needed to address a global unmet

338 need for the COVID-19 pandemic and CoV pandemics of the future.

\section{$340 \quad$ Figure Legends}

341 Figure 1. Chemical Structure and in vitro potency of GS-621763 in comparison to RDV

342 (GS-5734) and GS-441524.

343 (A) Chemical structure of the parental adenosine nucleoside analog GS-441524.

344 (B) Chemical structure of the monophosphoramidate prodrug RDV.

345 (C) Chemical structure of GS-621763, the tri-isobutyryl ester of GS-441524.

346 (D) Mean percent inhibition of SARS-CoV-2 replication by GS-621763, in comparison to the

347 prodrug RDV - and the parental nucleoside GS-441524 in A459-hACE2 cells (done in

348 triplicates).

349 (E) Cytotoxicity in A459-hACE2 cells treated with GS-621763, RDV, and GS-441524 in A459-

350 hACE2 cells (done in triplicates, CellTiter-Glo - CTG).

351 (F) Inhibition of SARS-CoV-2 replication by GS-621763, in comparison to the prodrug RDV

352 and the parental nucleoside GS-441524 in human primary airway epithelial cells (HAE, done in 353 duplicates). 
354 (G) Inhibition of SARS-CoV-2-Fluc replication by GS-621763, RDV -, and the parental nucleoside GS-441524 in normal human bronchial epithelial (NHBE) cultures (done in

356 duplicates).

$357(\mathrm{H})$ In vitro $\mathrm{EC}_{50}$ values for inhibition of viral replication by GS-621763, RDV, and the parental 358 nucleoside GS-441524 in A459-hACE2 and NHBE cells.

Figure 2. Dose-dependent therapeutic protection against COVID-19 disease by GS-621763

361 in mice.

362 (A) Plasma Pharmacokinetics of GS-441524 in uninfected Balb/c mice following a single oral

363 administration of GS-621763 at either 5 or $20 \mathrm{mg} / \mathrm{kg}$. Plasma concentrations of GS-621763 were

364 below the limit of quantification at all time points.

365 (B) Depicted is the \% starting weight in therapeutically treated mice with vehicle ( $\mathrm{n}=19)$ or 3

$366 \mathrm{mg} / \mathrm{kg}(\mathrm{n}=9), 10 \mathrm{mg} / \mathrm{kg}(\mathrm{n}=10)$, and $30 \mathrm{mg} / \mathrm{kg}(\mathrm{n}=10) \mathrm{GS}-621763$ at $8 \mathrm{hr}$. All mice were infected 367 with $1 \times 10^{4}$ PFU SARS-CoV-2 MA10.

368 (C) Lung viral titers in therapeutically treated mice with vehicle $(\mathrm{n}=19)$ or $3 \mathrm{mg} / \mathrm{kg}(\mathrm{n}=9), 10$

$369 \mathrm{mg} / \mathrm{kg}(\mathrm{n}=10)$, and $30 \mathrm{mg} / \mathrm{kg}(\mathrm{n}=10)$ GS-621763 at $8 \mathrm{hr}$. All mice were infected with $1 \times 10^{4} \mathrm{PFU}$

370 SARS-CoV-2 MA10. Limit of detection (LoD)

371 (D) Pulmonary function in therapeutically treated mice with vehicle $(\mathrm{n}=4)$ or $3 \mathrm{mg} / \mathrm{kg}(\mathrm{n}=4), 10$

$372 \mathrm{mg} / \mathrm{kg}(\mathrm{n}=4)$, and $30 \mathrm{mg} / \mathrm{kg}(\mathrm{n}=4)$ GS-621763 at $8 \mathrm{hr}$. All mice were infected with $1 \times 10^{4}$ PFU

373 SARS-CoV-2 MA10.

374 (E) Lung congestion score in therapeutically treated mice with vehicle $(\mathrm{n}=19)$ or $3 \mathrm{mg} / \mathrm{kg}(\mathrm{n}=9)$,

$37510 \mathrm{mg} / \mathrm{kg}(\mathrm{n}=10)$, and $30 \mathrm{mg} / \mathrm{kg}(\mathrm{n}=10) \mathrm{GS}-621763$ at $8 \mathrm{hr}$. All mice were infected with $1 \times 10^{4}$ 
377 (F and G) Lung pathology in the therapeutically treated mice with vehicle ( $\mathrm{n}=19)$ or $3 \mathrm{mg} / \mathrm{kg}$

$378(\mathrm{n}=9), 10 \mathrm{mg} / \mathrm{kg}(\mathrm{n}=10)$, and $30 \mathrm{mg} / \mathrm{kg}(\mathrm{n}=10) \mathrm{GS}-621763 \mathrm{at} 8 \mathrm{hr}$. All mice were infected with

$3791 \times 10^{4}$ PFU SARS-CoV-2 MA10.

380 Data were analyzed using two-way ANOVA (weight loss and lung function) and Kruskal-Wallis

381 test (lung titer, congestion score, and pathology scores), ${ }^{*} \mathrm{p}<0.05,{ }^{* *} \mathrm{p}<0.005, * * * \mathrm{p}<0.0005$,

$382 * * * * \mathrm{p}<0.0001$

383

Figure 3. Extended therapeutic protection of mice against COVID-19 disease by oral GS-

621763 in mice.

(A) Depicted is the $\%$ starting weight in therapeutically treated mice with either $30 \mathrm{mg} / \mathrm{kg}$ or 60 $\mathrm{mg} / \mathrm{kg}$ BID or QD GS-621763 at 12 and $24 \mathrm{hrs}$ ( $\mathrm{n}=10$ for all treatment groups, except $\mathrm{n}=8$ for 60 $\mathrm{mg} / \mathrm{kg}, 12 \mathrm{hr}$ QD treatment group). All mice were infected with 1x10 PFU SARS-CoV-2 MA10.

(B) Lung viral titers in therapeutically treated mice with either $30 \mathrm{mg} / \mathrm{kg}$ or $60 \mathrm{mg} / \mathrm{kg}$ BID or QD

GS-621763 at 12 and 24hrs ( $\mathrm{n}=10$ for all treatment groups, except $\mathrm{n}=8$ for $60 \mathrm{mg} / \mathrm{kg}, 12 \mathrm{hr}$ QD treatment group). All mice were infected with $1 \times 10^{4}$ PFU SARS-CoV-2 MA10. Limit of

393 detection $(\mathrm{LoD})$.

394 (C) Viral N RNA in therapeutically treated mice with either $30 \mathrm{mg} / \mathrm{kg}$ or $60 \mathrm{mg} / \mathrm{kg}$ BID or QD

395 GS-621763 at 12 and $24 \mathrm{hrs}$ ( $\mathrm{n}=10$ for all treatment groups, except $\mathrm{n}=8$ for $60 \mathrm{mg} / \mathrm{kg}, 12 \mathrm{hr}$ QD

396 treatment group). All mice were infected with $1 \times 10^{4}$ PFU SARS-CoV-2 MA10.

397 (D) Pulmonary function in therapeutically treated mice with either $30 \mathrm{mg} / \mathrm{kg}$ or $60 \mathrm{mg} / \mathrm{kg} \mathrm{BID}$ or 398 QD GS-621763 at 12 and $24 \mathrm{hrs}$ ( $\mathrm{n}=4$ for all treatment groups). All mice were infected with $3991 \times 10^{4}$ PFU SARS-CoV-2 MA10. 
$400 \quad(\mathrm{n}=4$ for all treatment groups).

401 (F and G) Lung pathology in the therapeutically treated mice with either $30 \mathrm{mg} / \mathrm{kg}$ or $60 \mathrm{mg} / \mathrm{kg}$

402 BID or QD GS-621763 at 12 and $24 \mathrm{hrs}(\mathrm{n}=10$ for all treatment groups, except $\mathrm{n}=8$ for $60 \mathrm{mg} / \mathrm{kg}$,

$40312 \mathrm{hr}$ QD treatment group, and n=7 for vehicle group).

404 Data were analyzed using two-way ANOVA (weight loss and lung function) and Kruskal-Wallis

405 test (lung titer, lung viral RNA, and pathology scores), $* \mathrm{p}<0.05, * * \mathrm{p}<0.005, * * * \mathrm{p}<0.0005$, $* * * * \mathrm{p}<0.0001$

Figure 4. Evaluation of therapeutic intervention of GS-621763 in comparison to

409 molnupiravir (MPV).

410 (A) Depicted is the \% starting weight in therapeutically treated mice with either $30 \mathrm{mg} / \mathrm{kg}$ or 60

$411 \mathrm{mg} / \mathrm{kg} \mathrm{GS}-621763$ or MPV at 12 or $24 \mathrm{hrs}(\mathrm{n}=10$ for all treatment groups). All mice were

412 infected with $1 \times 10^{4}$ PFU SARS-CoV-2 MA10.

413 (B) Lung viral titers in therapeutically treated mice with either $30 \mathrm{mg} / \mathrm{kg}$ or $60 \mathrm{mg} / \mathrm{kg} \mathrm{GS}$ -

414621763 or MPV at 12 or $24 \mathrm{hrs}(\mathrm{n}=10$ for all treatment groups). All mice were infected with

$4151 \times 10^{4}$ PFU SARS-CoV-2 MA10. Limit of detection (LoD).

416 (C) Viral N RNA in therapeutically treated mice with either $30 \mathrm{mg} / \mathrm{kg}$ or $60 \mathrm{mg} / \mathrm{kg}$ GS-621763

417 or MPV at 12 or $24 \mathrm{hrs}$ ( $\mathrm{n}=10$ for all treatment groups). All mice were infected with $1 \times 10^{4} \mathrm{PFU}$

418 SARS-CoV-2 MA10.

419 (D) Pulmonary function in therapeutically treated mice with either $30 \mathrm{mg} / \mathrm{kg}$ or $60 \mathrm{mg} / \mathrm{kg}$ GS-

420621763 or MPV at 12 or $24 \mathrm{hrs}\left(\mathrm{n}=4\right.$ for all treatment groups). All mice were infected with $1 \times 10^{4}$

421 PFU SARS-CoV-2 MA10. 
422 (F and G) Lung pathology in the therapeutically treated mice with either $30 \mathrm{mg} / \mathrm{kg}$ or $60 \mathrm{mg} / \mathrm{kg}$

423 GS-621763 or MPV at 12or $24 \mathrm{hrs} \mathrm{(n=10} \mathrm{for} \mathrm{all} \mathrm{treatment} \mathrm{groups).} \mathrm{All} \mathrm{mice} \mathrm{were} \mathrm{infected} \mathrm{with}$

$4241 \times 10^{4}$ PFU SARS-CoV-2 MA10.

425 Data were analyzed using two-way ANOVA (weight loss and lung function) and Kruskal-Wallis

426 test (lung titer, lung viral RNA, and pathology scores), ${ }^{*} \mathrm{p}<0.05,{ }^{*} \mathrm{p}<0.005, * * * \mathrm{p}<0.0005$,

$427 \quad * * * * \mathrm{p}<0.0001$

428

Supplemental Figure 1. In vitro potency and toxicity of GS-621763, RDV, and GS-441524

\section{in A549-hACE2 cells}

431 (A) Raw data for the inhibition of SARS-CoV-2 replication by GS-621763, RDV, and GS-

432441521 in A459-hACE2 cells measured through quantitation of SARS-CoV-2 expressed nano

433 luciferase (nLuc), measured in triplicates.

434 (B) Raw data for cytotoxicity in A459-hACE2 cells treated with GS-621763, RDV, and GS-

435441521 in A459-hACE2 cells measured via CellTiter-Glo, (measured in triplicates).

436 C) Raw data for the inhibition of SARS-CoV-2-Fluc replication by GS-621763, RDV, and GS-

437441521 in NHBE cultures measured through quantitation of SARS-CoV-2 expressed firefly

438 luciferase (Fluc), measured in duplicates, repeated twice.

440 Supplemental Figure 2. Molnupiravir mouse plasma pharmacokinetics

441 Plasma Pharmacokinetics of N-hydroxycytidine (NHC) in uninfected Balb/c mice following

442 daily oral administration of molnupiravir at either 60 or $200 \mathrm{mg} / \mathrm{kg}$ (as either 30 or 100

$443 \mathrm{mg} / \mathrm{kg} /$ dose given BID; molnupiravir at all timepoints). 


\section{Material and Methods}

\section{Small molecule drug synthesis and formulation}

447 GS-621763, RDV, and GS-441524 were synthesized at Gilead Sciences Inc., and their chemical

448 identity and purity were determined by nuclear magnetic resonance, and high-performance

449 liquid chromatography (HPLC) analysis (27). Molnupiravir was purchased from

450 MedChemExpress LLC (NJ, USA) with a purity of $95 \%$ based on HPLC analysis.

451 Small molecules were solubilized in 100\% DMSO for in vitro studies and in vehicle

452 containing 2.5\% DMSO; 10\% Kolliphor HS-15; 10\% Labrasol; 2.5\% Propylene glycol; 75\%

453 Water (final formulation $\mathrm{pH}$ 2) (for GS-621763) and in vehicle containing $2.5 \%$ Kolliphor RH-

454 40, 10\% Polyethylene glycol 300, 87.5\% Water (for MPV) for in vivo studies. GS-621763, GS-

455441524 , GS-5734 were made available to the University of North Carolina (UNC) at Chapel Hill 456 under a materials transfer agreement with Gilead Sciences.

In vivo plasma pharmacokinetic analysis of GS-621763 and molnupiravir (MPV)

Mice were orally administered either a single dose of GS-621763 (in vehicle containing

$460 \quad 2.5 \%$ DMSO; 10\% Kolliphor HS-15; 10\% Labrasol; 2.5\% Propylene glycol; 75\% Water (final

461 formulation $\mathrm{pH}$ 2) or two doses of molnupiravir (in vehicle containing $2.5 \%$ Kolliphor RH-40,

$46210 \%$ Polyethylene glycol 300, 87.5\% Water) (BID, 12 hours apart). GS-621763 was given at

463 either 5 or $20 \mathrm{mg} / \mathrm{kg}$ and MPV at either 30 or $100 \mathrm{mg} / \mathrm{kg}$. Plasma was serially isolated from 4

464 mice at $0.25,1,2,8$ and 24 hrs post GS-621763 administration. Plasma was isolated from

465 alternating groups of 4 mice per timepoint at 0.5, 2, 6, 12 (pre-second dose), 12.5, 18 and 24

466 hrs post MPV administration. $20 \mu \mathrm{l}$ of plasma was added to a mixture containing $250 \mu 1$ of

467 methanol and $25 \mu \mathrm{L}$ of internal standard solution and centrifuged. $250 \mu \mathrm{l}$ of resulting 
supernatant was then transferred, filtered (Agilent Captiva 96, $0.2 \mu \mathrm{m}$ ) and dried under a stream

of nitrogen at $40{ }^{\circ} \mathrm{C}$. Following reconstitution in a mixture of $5 \%$ acetonitrile and $95 \%$ water, a

$47010 \mu \mathrm{l}$ aliquot was injected onto an LC-MS/MS system. Plasma concentrations of either GS-

471621763 and GS-441524 or MPV and N-hydroxycytidine (NHC) were determined using 8 to 10-

472 point calibration curves spanning at least 3 orders of magnitude with quality control samples to

473 ensure accuracy and precision, prepared in normal mouse plasma. Analytes were separated by a

$47450 \mathrm{~mm} \times 3.0 \mathrm{~mm}, 2.55 \mu \mathrm{m}$ Synergi Polar-RP column (Phenomenex) using a multi-stage linear

475 gradient from $5 \%$ to $95 \%$ acetonitrile in mobile phase A at a flow rate of $1 \mathrm{ml} / \mathrm{min}$.

Quantitation of GS-441524 metabolites in the lung following oral GS-621763

administration in $\mathrm{Balb} / \mathrm{c}$ mice

480 and immediately snap frozen in liquid nitrogen. On dry ice, frozen lung samples were

481 pulverized and weighed. Dry ice-cold extraction buffer containing $0.1 \%$ potassium hydroxide

482 and $67 \mathrm{mM}$ ethylenediamine tetraacetic acid (EDTA) in $70 \%$ methanol, containing $0.5 \mu \mathrm{M}$

483 chloro-adenosine triphosphate as internal standard was added and homogenized. After

484 centrifugation at $20,000 \times \mathrm{g}$ for 20 minutes, supernatants were transferred and dried in a

485 centrifuging evaporator. Dried samples were then reconstituted with $60 \mu \mathrm{L}$ of mobile phase A,

486 containing $3 \mathrm{mM}$ ammonium formate (pH 5) with $10 \mathrm{mM}$ dimethylhexylamine (DMH) in

487 water, centrifuged at $20,000 \times \mathrm{g}$ for 20 minutes and final supernatants transferred to HPLC

488 injection vials. An aliquot of $10 \mu \mathrm{l}$ was subsequently injected onto an API $6500 \mathrm{LC} / \mathrm{MS} / \mathrm{MS}$

489 system for analysis of GS-441524 and its phosphorylated metabolites, performed using a

490 similar method as described previously (18). 
Version 9.4

\section{Viruses and plaque assay}

Recombinant SARS-CoV-2 MA10 virus was generated as described previously (30). For

494 virus titration by plaque assay, the caudal lobe of the right lung was homogenized in PBS, and

495 the resulting homogenate was serial-diluted and inoculated onto confluent monolayers of Vero

496 E6 cells, followed by agarose overlay. Plaques were visualized with overlay of neutral red dye

497 on day 3 after infection (30).

\section{In vitro assays for antiviral activity}

A549-hACE2 cells were plated at a density of 20,000 cells/well/100 $\mu \mathrm{l}$ in black-walled

501 clear-bottom 96-well plates 24 hrs prior to infection. Compounds GS-621763, GS-5734, GS-

502441524 , were diluted in 100\% DMSO (1:3) resulting in a 1000X dose response from 10 to 0.002

$503 \mathrm{mM}$ (10 to $0.002 \mu \mathrm{M}$ final). All conditions were performed in triplicate. At BSL3, medium was

504 removed, and cells were infected with $100 \mu \mathrm{l} \mathrm{SARS-CoV-2} \mathrm{nLUC} \mathrm{(MOI} \mathrm{0.008)} \mathrm{for} 1 \mathrm{~h}$ at $37^{\circ} \mathrm{C}$

505 after which virus was removed, wells were washed (150 $\mu 1)$ with infection media (DMEM, 4\%

506 FBS, $1 \mathrm{X}$ antibiotic/antimycotic) and infection media $(100 \mu 1)$ containing a dose response of drug

507 was added. Plates were incubated at $37^{\circ} \mathrm{C}$ for $48 \mathrm{hrs}$. NanoGlo assay was performed 48 hpi.

508 Sister plates were exposed to drug but not infected to gauge cytotoxicity via CellTiter-Glo assay

509 (CTG, Promega, Madison, WI), 48 hrs post treatment.

$510 \quad$ Normal human bronchial epithelial (NHBE) cells (donor 41219) were purchased from

511 Lonza (Walkersville, MD Cat\# CC-2540) and maintained in Bronchial Epithelial Cell Growth

512 Medium (BEGM) (Lonza, Walkersville, MD, Cat\# CC-3170) with all provided supplements in

513 the BulletKit. Cells are passaged 2-3 times per week to maintain sub-confluent densities and are 
514 used for experiments at passages 2-4. NHBE cells were seeded in 24-well plates at $1 \times 10^{5}$ cells in

515 a final volume of $0.5 \mathrm{ml} \mathrm{BEGM}{ }^{\mathrm{TM}}$ Bronchial Epithelial Cell Growth Medium (BulletKit ${ }^{\mathrm{TM}}$;

516 Lonza, Basel, SW). Cultures were incubated overnight $37^{\circ} \mathrm{C}$ with $5 \% \mathrm{CO}_{2}$. On the following

517 day, media was replaced with $0.5 \mathrm{ml}$ growth medium. Cultures were treated with 1:3 serial

518 dilutions of compound using the HP D300e digital dispenser with normalization to the highest

519 concentration of DMSO in all wells ( $<1 \%$ final volume). The cells were then infected with 0.1

$520 \mathrm{ml}$ SARS-CoV-2-Fluc diluted in BEGM media at MOI $=5$. Uninfected and untreated wells were

521 included as controls to determine compound efficacy against SARS-CoV-2-Fluc. Following

522 incubation with compound and virus for $24 \mathrm{hrs}$ at $37{ }^{\circ} \mathrm{C}$ with $5 \% \mathrm{CO}_{2}$, culture supernatant was

523 removed from each well and replaced with $0.3 \mathrm{ml}$ of ONE-Glo luciferase reagent (Promega,

524 Madison, WI). The plates were shaken at $400 \mathrm{rpm}$ for $10 \mathrm{~min}$ at room temperature. $0.2 \mathrm{ml}$ of

525 supernatant from each well was transferred to a 96-well opaque plate (Corning) and

526 luminescence signal was measured using an EnVision plate reader (PerkinElmer). Values were

527 normalized to the uninfected and infected DMSO controls $(0 \%$ and $100 \%$ infection,

528 respectively). Data was fit using a four-parameter non-linear regression analysis using Graphpad

529 Prism. $\mathrm{EC}_{50}$ values were then determined as the concentration reducing the firefly luciferase

530 signal by $50 \%$. The compiled data was generated based on least two independent experimental

531 replicates, each containing four technical replicates for each concentration.

\section{Mouse studies and in vivo infections}

533 All mouse studies were performed at the University of North Carolina (Animal Welfare

534 Assurance \#A3410-01) using protocols (\#20-059) approved by the University of North Carolina

535 Institutional Animal Care and Use Committee. All animal work was approved by the

536 Institutional Animal Care and Use Committee at University of North Carolina at Chapel Hill 
537 according to guidelines outlined by the Association for the Assessment and Accreditation of

538 Laboratory Animal Care and the US Department of Agriculture. All work was performed with

539 approved standard operating procedures and safety conditions for SARS-CoV-2. Our

540 institutional BSL3 facilities are designed to conform to the safety requirements recommended by

541 Biosafety in Microbiological and Biomedical Laboratories, the US Department of Health and

542 Human Services, the Public Health Service, the Centers for Disease Control and Prevention, and

543 the National Institutes of Health. Laboratory safety plans have been submitted, and the facility

544 has been approved for use by the University of North Carolina Department of Environmental

545 Health and Safety and the Centers for Disease Control and Prevention.

Even groups ( $\mathrm{n}=10$, or less as indicated) of 10-week-old female BALB/c mice (Envigo;

$547 \# 047)$ were used in all in vivo efficacy studies. For infection, mice were anesthetized with a

548 mixture of ketamine/xylazine and infected with $10^{4} \mathrm{PFU}$ of SARS-CoV-2 MA10 in $50 \mu 1 \mathrm{PBS}$

549 intranasally. Vehicle or GS-621673 was administered orally at the dosages and timepoints as

550 indicated. Mice were monitored daily for body weight changes and for lung function by whole-

551 body plethysmography. At 4 dpi, mice were euthanized, and lung tissue was harvested for viral

552 titer analysis, RNA and histology, and lung congestion scores were estimated (30). Samples for

553 viral load determination and for RNA isolation were stored at $-80{ }^{\circ} \mathrm{C}$ until used; histology

554 samples were inactivated in $10 \% \mathrm{NBF}$ and stored at $4{ }^{\circ} \mathrm{C}$ until further processing.

556 Histology and lung pathology scoring

Two separate lung pathology scoring scales, Matute-Bello and Diffuse Alveolar Damage

558 (DAD), were used to quantify acute lung injury (ALI) (19).

For Matute-Bello scoring samples were blinded and three random fields of lung tissue 
$1,>5$ cells $=2),(B)$ neutrophils in interstitial space (none $=0,1-5$ cells $=1,>5$ cells $=2),(C)$

hyaline membranes (none $=0$, one membrane $=1,>1$ membrane $=2$ ), (D) Proteinaceous debris

563 in air spaces (none $=0$, one instance $=1,>1$ instance $=2),($ E) alveolar septal thickening $(<2 \AA \sim$

564 mock thickness $=0,2-4 \AA \sim$ mock thickness $=1,>4 \AA \sim$ mock thickness $=2$ ). Scores from $\mathrm{A}-\mathrm{E}$

565 were put into the following formula score $=[(20 \times \mathrm{A})+(14 \times \mathrm{B})+(7 \times \mathrm{C})+(7 \times \mathrm{D})+(2 \times \mathrm{E})] / 100$

566 to obtain a lung injury score per field and then averaged for the final score for that sample.

In a similar way, for DAD scoring, three random fields of lung tissue were scored for the

568 in a blinded manner for: $1=$ absence of cellular sloughing and necrosis, $2=$ uncommon solitary cell

569 sloughing and necrosis ( $1-2$ foci/field), $3=$ multifocal $(3+$ foci) cellular sloughing and necrosis with

570 uncommon septal wall hyalinization, or $4=$ multifocal $(>75 \%$ of field) cellular sloughing and

571 necrosis with common and/or prominent hyaline membranes. To obtain the final DAD score per

572 mouse, the scores for the three fields per mouse were averaged.

\section{RNA isolation and RT-qPCR}

Mouse tissue from SARS-CoV-2 infected mice was homogenized using glass beads in

575 TRIzol Reagent (Invitrogen). Equal volume of 100\% EtOH was mixed with the TRIzol

576 homogenate and processed using Direct-Zol RNA MiniPrep Kit (Zymo) to extract viral RNA.

577 Optional DNase I treatment was conducted to ensure the adequate removal of unwanted DNA.

578 Eluted RNA was coupled with TaqMan Fast Virus 1-step Master Mix (Applied Biosystems) and

579 nCOV_N1 primers/probe (IDT) to quantify viral load via reverse transcription - quantitative

580 polymerase chain reaction (RT-qPCR). Samples were plated on a MicroAmp EnduraPlate

581 (Applied Biosystems) and run using a QuantStudio 6 Real-Time PCR System (Applied

582 Biosystems) to obtain viral titers. The following PCR program was run: $50{ }^{\circ} \mathrm{C}$ for 5 minutes, 95 
$583{ }^{\circ} \mathrm{C}$ for 20 seconds, followed by 45 cycles of $95{ }^{\circ} \mathrm{C}$ for 3 seconds and $60^{\circ} \mathrm{C}$ for 30 seconds. The

584 sequences of the 2019-nCOV_N1 primers and probe were as follows: Forward primer: GAC

585 CCC AAA ATC AGC GAA AT, Reverse primer: TCT GGT TAC TGC CAG TTG AAT CTG,

586 Probe: AC CCC GCA TT ACG TTT GGT GGA CC (CDC N1 qRT-PCR assay (42). SARS-

587 CoV-2 standard curve RNA was produced by PCR amplification of SARS-CoV-2 nucleocapsid

588 by which a 5' $\mathrm{T} 7$ polymerase promoter was introduced. This amplicon was used as template to

589 generate in vitro transcribed RNA which was then quantified and serially diluted (108- 101

590 copies/ $\mu 1)$.

\section{Acknowledgement}

592 D.R.M. is funded by a Burroughs Wellcome Fund Postdoctoral Enrichment Program Award and a Hanna

593 H. Gray Fellowship from the Howard Hughes Medical Institute and was supported by an NIH NIAID T32

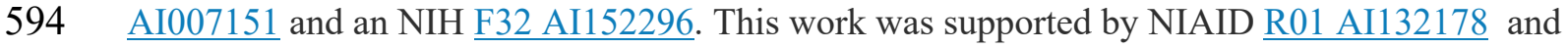

595 R01AI132178-04S1 (T.P.S. and R.S.B.) and an NIH animal models contract (HHSN2722017000361) to

596 R.S.B. This project was supported in part by the North Carolina Policy Collaboratory at University of

597 North Carolina at Chapel Hill with funding from the North Carolina Coronavirus Relief Fund established

598 and appropriated by the North Carolina General Assembly.

599 Animal histopathology services were performed by the Animal Histopathology \& Laboratory Medicine

600 Core at the University of North Carolina, which is supported in part by an NCI Center Core Support

601 Grant (5P30CA016086-41) to the UNC Lineberger Comprehensive Cancer Center.

602

603 Competing interest

604 These authors are employees of Gilead Sciences and hold stock in Gilead Sciences: Rao Kalla, 605 Kwon Chun, Venice Du Pont, Darius Babusis, Jennifer Tang, Eisuke Murakami, Raju 
Subramanian, Kimberly T Barrett, Blake J. Bleier, Roy Bannister, Joy Y. Feng, John P. Bilello,

\section{Literature}

610 1. P. Zhou, X. L. Yang, X. G. Wang, B. Hu, L. Zhang, W. Zhang, H. R. Si, Y. Zhu, B. Li, C. L. Huang, H. D. Chen, J. Chen, Y. Luo, H. Guo, R. D. Jiang, M. Q. Liu, Y. Chen, X. R. Shen, X. Wang, X. S. Zheng, K. Zhao, Q. J. Chen, F. Deng, L. L. Liu, B. Yan, F. X. Zhan, Y. Y. Wang, G. F. Xiao, Z. L. Shi, A pneumonia outbreak associated with a new coronavirus of probable bat origin. Nature 579, 270-273 (2020).

2. N. Zhu, D. Zhang, W. Wang, X. Li, B. Yang, J. Song, X. Zhao, B. Huang, W. Shi, R. Lu, P. Niu, F. Zhan, X. Ma, D. Wang, W. Xu, G. Wu, G. F. Gao, W. Tan, I. China Novel Coronavirus, T. Research, A Novel Coronavirus from Patients with Pneumonia in China, 2019. N Engl J Med 382, 727-733 (2020).

3. J. H. University. (2020).

4. A. Binagwaho, K. Mathewos, S. Davis, Time for the ethical management of COVID-19 vaccines. Lancet Glob Health, (2021).

5. E. Aryeetey, E. Engebretsen, A. Gornitzka, P. Maassen, S. Stolen, A step backwards in the fight against global vaccine inequities. Lancet 397, 23-24 (2021).

6. A. Asundi, C. O'Leary, N. Bhadelia, Global COVID-19 vaccine inequity: The scope, the impact, and the challenges. Cell Host Microbe 29, 1036-1039 (2021).

7. J. R. Barrett, S. Belij-Rammerstorfer, C. Dold, K. J. Ewer, P. M. Folegatti, C. Gilbride, R. Halkerston, J. Hill, D. Jenkin, L. Stockdale, M. K. Verheul, P. K. Aley, B. Angus, D. Bellamy, E. Berrie, S. Bibi, M. Bittaye, M. W. Carroll, B. Cavell, E. A. Clutterbuck, N. Edwards, A. Flaxman, M. Fuskova, A. Gorringe, B. Hallis, S. Kerridge, A. M. Lawrie, A. Linder, X. Liu, M. Madhavan, R. Makinson, J. Mellors, A. Minassian, M. Moore, Y. Mujadidi, E. Plested, I. Poulton, M. N. Ramasamy, H. Robinson, C. S. Rollier, R. Song, M. D. Snape, R. Tarrant, S. Taylor, K. M. Thomas, M. Voysey, M. E. E. Watson, D. Wright, A. D. Douglas, C. M. Green, A. V. S. Hill, T. Lambe, S. Gilbert, A. J. Pollard, C. V. T. G. Oxford, Phase 1/2 trial of SARS-CoV-2 vaccine ChAdOx1 nCoV-19 with a booster dose induces multifunctional antibody responses. Nat Med 27, 279-288 (2021).

8. J. Grein, N. Ohmagari, D. Shin, G. Diaz, E. Asperges, A. Castagna, T. Feldt, G. Green, M. L. Green, F. X. Lescure, E. Nicastri, R. Oda, K. Yo, E. Quiros-Roldan, A. Studemeister, J. Redinski, S. Ahmed, J. Bernett, D. Chelliah, D. Chen, S. Chihara, S. H. Cohen, J. Cunningham, A. D'Arminio Monforte, S. Ismail, H. Kato, G. Lapadula, E. L'Her, T. Maeno, S. Majumder, M. Massari, M. Mora-Rillo, Y. Mutoh, D. Nguyen, E. Verweij, A. Zoufaly, A. O. Osinusi, A. DeZure, Y. Zhao, L. Zhong, A. Chokkalingam, E. Elboudwarej, L. Telep, L. Timbs, I. Henne, S. Sellers, H. Cao, S. K. Tan, L. Winterbourne, P. Desai, R. Mera, A. Gaggar, R. P. Myers, D. M. Brainard, R. Childs, T. Flanigan, Compassionate Use of Remdesivir for Patients with Severe Covid-19. N Engl J Med 382, 2327-2336 (2020). 
Version 9.4

646

9. J. H. Beigel, K. M. Tomashek, L. E. Dodd, A. K. Mehta, B. S. Zingman, A. C. Kalil, E. Hohmann, H. Y. Chu, A. Luetkemeyer, S. Kline, D. Lopez de Castilla, R. W. Finberg, K. Dierberg, V. Tapson, L. Hsieh, T. F. Patterson, R. Paredes, D. A. Sweeney, W. R. Short, G. Touloumi, D. C. Lye, N. Ohmagari, M. D. Oh, G. M. Ruiz-Palacios, T. Benfield, G. Fatkenheuer, M. G. Kortepeter, R. L. Atmar, C. B. Creech, J. Lundgren, A. G. Babiker, S. Pett, J. D. Neaton, T. H. Burgess, T. Bonnett, M. Green, M. Makowski, A. Osinusi, S. Nayak, H. C. Lane, A.-S. G. Members, Remdesivir for the Treatment of Covid-19 - Final Report. N Engl J Med 383, 1813-1826 (2020).

10. D. F. Robbiani, C. Gaebler, F. Muecksch, J. C. C. Lorenzi, Z. Wang, A. Cho, M. Agudelo, C. O. Barnes, A. Gazumyan, S. Finkin, T. Hagglof, T. Y. Oliveira, C. Viant, A. Hurley, H. H. Hoffmann, K. G. Millard, R. G. Kost, M. Cipolla, K. Gordon, F. Bianchini, S. T. Chen, V. Ramos, R. Patel, J. Dizon, I. Shimeliovich, P. Mendoza, H. Hartweger, L. Nogueira, M. Pack, J. Horowitz, F. Schmidt, Y. Weisblum, E. Michailidis, A. W. Ashbrook, E. Waltari, J. E. Pak, K. E. Huey-Tubman, N. Koranda, P. R. Hoffman, A. P. West, Jr., C. M. Rice, T. Hatziioannou, P. J. Bjorkman, P. D. Bieniasz, M. Caskey, M. C. Nussenzweig, Convergent antibody responses to SARS-CoV-2 in convalescent individuals. Nature 584, 437-442 (2020).

11. S. J. Zost, P. Gilchuk, R. E. Chen, J. B. Case, J. X. Reidy, A. Trivette, R. S. Nargi, R. E. Sutton, N. Suryadevara, E. C. Chen, E. Binshtein, S. Shrihari, M. Ostrowski, H. Y. Chu, J. E. Didier, K. W. MacRenaris, T. Jones, S. Day, L. Myers, F. Eun-Hyung Lee, D. C. Nguyen, I. Sanz, D. R. Martinez, P. W. Rothlauf, L. M. Bloyet, S. P. J. Whelan, R. S. Baric, L. B. Thackray, M. S. Diamond, R. H. Carnahan, J. E. Crowe, Jr., Rapid isolation and profiling of a diverse panel of human monoclonal antibodies targeting the SARSCoV-2 spike protein. Nat Med 26, 1422-1427 (2020).

12. D. Pinto, Y. J. Park, M. Beltramello, A. C. Walls, M. A. Tortorici, S. Bianchi, S. Jaconi, K. Culap, F. Zatta, A. De Marco, A. Peter, B. Guarino, R. Spreafico, E. Cameroni, J. B. Case, R. E. Chen, C. Havenar-Daughton, G. Snell, A. Telenti, H. W. Virgin, A. Lanzavecchia, M. S. Diamond, K. Fink, D. Veesler, D. Corti, Cross-neutralization of SARS-CoV-2 by a human monoclonal SARS-CoV antibody. Nature 583, 290-295 (2020).

13. A.-T. L.-C. S. Group, J. D. Lundgren, B. Grund, C. E. Barkauskas, T. L. Holland, R. L. Gottlieb, U. Sandkovsky, S. M. Brown, K. U. Knowlton, W. H. Self, D. C. Files, M. K. Jain, T. Benfield, M. E. Bowdish, B. G. Leshnower, J. V. Baker, J. U. Jensen, E. M. Gardner, A. A. Ginde, E. S. Harris, I. S. Johansen, N. Markowitz, M. A. Matthay, L. Ostergaard, C. C. Chang, V. J. Davey, A. Goodman, E. S. Higgs, D. D. Murray, T. A. Murray, R. Paredes, M. K. B. Parmar, A. N. Phillips, C. Reilly, S. Sharma, R. L. Dewar, M. Teitelbaum, D. Wentworth, H. Cao, P. Klekotka, A. G. Babiker, A. C. Gelijns, V. L. Kan, M. N. Polizzotto, B. T. Thompson, H. C. Lane, J. D. Neaton, A Neutralizing Monoclonal Antibody for Hospitalized Patients with Covid-19. N Engl J Med 384, 905914 (2021).

14. M. P. O'Brien, E. Forleo-Neto, B. J. Musser, F. Isa, K. C. Chan, N. Sarkar, K. J. Bar, R. V. Barnabas, D. H. Barouch, M. S. Cohen, C. B. Hurt, D. R. Burwen, M. A. Marovich, P. Hou, I. Heirman, J. D. Davis, K. C. Turner, D. Ramesh, A. Mahmood, A. T. Hooper, J. D. Hamilton, Y. Kim, L. A. Purcell, A. Baum, C. A. Kyratsous, J. Krainson, R. PerezPerez, R. Mohseni, B. Kowal, A. T. DiCioccio, N. Stahl, L. Lipsich, N. Braunstein, G. Herman, G. D. Yancopoulos, D. M. Weinreich, T. Covid-19 Phase 3 Prevention Trial, 
Version 9.4

692

693

694

695

696

697

698

699

700

701

702

703

704

705

706

707

708

709

710

711

712

713

714

715

716

717

718

719

720

721

722

723

724

725

726

727

728

729

730

731

732

733

734

735

736

737

Subcutaneous REGEN-COV Antibody Combination to Prevent Covid-19. N Engl J Med, (2021).

15. R. E. Chen, X. Zhang, J. B. Case, E. S. Winkler, Y. Liu, L. A. VanBlargan, J. Liu, J. M. Errico, X. Xie, N. Suryadevara, P. Gilchuk, S. J. Zost, S. Tahan, L. Droit, J. S. Turner, W. Kim, A. J. Schmitz, M. Thapa, D. Wang, A. C. M. Boon, R. M. Presti, J. A. O'Halloran, A. H. J. Kim, P. Deepak, D. Pinto, D. H. Fremont, J. E. Crowe, Jr., D. Corti, H. W. Virgin, A. H. Ellebedy, P. Y. Shi, M. S. Diamond, Resistance of SARS-CoV-2 variants to neutralization by monoclonal and serum-derived polyclonal antibodies. Nat Med 27, 717-726 (2021).

16. P. Wang, M. S. Nair, L. Liu, S. Iketani, Y. Luo, Y. Guo, M. Wang, J. Yu, B. Zhang, P. D. Kwong, B. S. Graham, J. R. Mascola, J. Y. Chang, M. T. Yin, M. Sobieszczyk, C. A. Kyratsous, L. Shapiro, Z. Sheng, Y. Huang, D. D. Ho, Antibody resistance of SARSCoV-2 variants B.1.351 and B.1.1.7. Nature 593, 130-135 (2021).

17. D. R. Martinez, A. Schäfer, S. R. Leist, D. Li, K. Gully, B. Yount, J. Y. Feng, E. Bunyan, D. P. Porter, T. Cihlar, S. A. Montgomery, B. F. Haynes, R. S. Baric, M. C. Nussenzweig, T. P. Sheahan, Prevention and therapy of SARS-CoV-2 and the B.1.351 variant in mice. Cell Rep 36, 109450 (2021).

18. T. P. Sheahan, A. C. Sims, R. L. Graham, V. D. Menachery, L. E. Gralinski, J. B. Case, S. R. Leist, K. Pyrc, J. Y. Feng, I. Trantcheva, R. Bannister, Y. Park, D. Babusis, M. O. Clarke, R. L. Mackman, J. E. Spahn, C. A. Palmiotti, D. Siegel, A. S. Ray, T. Cihlar, R. Jordan, M. R. Denison, R. S. Baric, Broad-spectrum antiviral GS-5734 inhibits both epidemic and zoonotic coronaviruses. Sci Transl Med 9, (2017).

19. T. P. Sheahan, A. C. Sims, S. R. Leist, A. Schafer, J. Won, A. J. Brown, S. A. Montgomery, A. Hogg, D. Babusis, M. O. Clarke, J. E. Spahn, L. Bauer, S. Sellers, D. Porter, J. Y. Feng, T. Cihlar, R. Jordan, M. R. Denison, R. S. Baric, Comparative therapeutic efficacy of remdesivir and combination lopinavir, ritonavir, and interferon beta against MERS-CoV. Nat Commun 11, 222 (2020).

20. T. P. Sheahan, A. C. Sims, S. Zhou, R. L. Graham, A. J. Pruijssers, M. L. Agostini, S. R. Leist, A. Schafer, K. H. Dinnon, 3rd, L. J. Stevens, J. D. Chappell, X. Lu, T. M. Hughes, A. S. George, C. S. Hill, S. A. Montgomery, A. J. Brown, G. R. Bluemling, M. G. Natchus, M. Saindane, A. A. Kolykhalov, G. Painter, J. Harcourt, A. Tamin, N. J. Thornburg, R. Swanstrom, M. R. Denison, R. S. Baric, An orally bioavailable broadspectrum antiviral inhibits SARS-CoV-2 in human airway epithelial cell cultures and multiple coronaviruses in mice. Sci Transl Med 12, (2020).

21. A. Wahl, L. E. Gralinski, C. E. Johnson, W. Yao, M. Kovarova, K. H. Dinnon, 3rd, H. Liu, V. J. Madden, H. M. Krzystek, C. De, K. K. White, K. Gully, A. Schafer, T. Zaman, S. R. Leist, P. O. Grant, G. R. Bluemling, A. A. Kolykhalov, M. G. Natchus, F. B. Askin, G. Painter, E. P. Browne, C. D. Jones, R. J. Pickles, R. S. Baric, J. V. Garcia, SARSCoV-2 infection is effectively treated and prevented by EIDD-2801. Nature 591, 451-457 (2021).

22. W. Fischer, J. J. Eron, W. Holman, M. S. Cohen, L. Fang, L. J. Szewczyk, T. P. Sheahan, R. Baric, K. R. Mollan, C. R. Wolfe, E. R. Duke, M. M. Azizad, K. Borroto-Esoda, D. A. Wohl, A. J. Loftis, P. Alabanza, F. Lipansky, W. P. Painter, Molnupiravir, an Oral Antiviral Treatment for COVID-19. medRxiv, (2021).

23. B. N. Williamson, F. Feldmann, B. Schwarz, K. Meade-White, D. P. Porter, J. Schulz, N. van Doremalen, I. Leighton, C. Kwe Yinda, L. Perez-Perez, A. Okumura, J. Lovaglio, P. 
Version 9.4

W. Hanley, G. Saturday, C. M. Bosio, S. Anzick, K. Barbian, T. Cihlar, C. Martens, D. P. Scott, V. J. Munster, E. de Wit, Clinical benefit of remdesivir in rhesus macaques infected with SARS-CoV-2. bioRxiv, (2020).

24. D. R. Owen, C. M. N. Allerton, A. S. Anderson, L. Aschenbrenner, M. Avery, S. Berritt, B. Boras, R. D. Cardin, A. Carlo, K. J. Coffman, A. Dantonio, L. Di, H. Eng, R. Ferre, K. S. Gajiwala, S. A. Gibson, S. E. Greasley, B. L. Hurst, E. P. Kadar, A. S. Kalgutkar, J. C. Lee, J. Lee, W. Liu, S. W. Mason, S. Noell, J. J. Novak, R. S. Obach, K. Ogilvie, N. C. Patel, M. Pettersson, D. K. Rai, M. R. Reese, M. F. Sammons, J. G. Sathish, R. S. P. Singh, C. M. Steppan, A. E. Stewart, J. B. Tuttle, L. Updyke, P. R. Verhoest, L. Wei, Q. Yang, Y. Zhu, An Oral SARS-CoV-2 $\mathrm{M}<$ sup $>$ pro $</$ sup $>$ Inhibitor Clinical Candidate for the Treatment of COVID-19. medRxiv, 2021.2007.2028.21261232 (2021).

25. S. S. Good, J. Westover, K. H. Jung, X. J. Zhou, A. Moussa, P. La Colla, G. Collu, B. Canard, J. P. Sommadossi, AT-527, a Double Prodrug of a Guanosine Nucleotide Analog, Is a Potent Inhibitor of SARS-CoV-2 In Vitro and a Promising Oral Antiviral for Treatment of COVID-19. Antimicrob Agents Chemother 65, (2021).

26. A. J. Pruijssers, A. S. George, A. Schafer, S. R. Leist, L. E. Gralinksi, K. H. Dinnon, 3rd, B. L. Yount, M. L. Agostini, L. J. Stevens, J. D. Chappell, X. Lu, T. M. Hughes, K. Gully, D. R. Martinez, A. J. Brown, R. L. Graham, J. K. Perry, V. Du Pont, J. Pitts, B. Ma, D. Babusis, E. Murakami, J. Y. Feng, J. P. Bilello, D. P. Porter, T. Cihlar, R. S. Baric, M. R. Denison, T. P. Sheahan, Remdesivir Inhibits SARS-CoV-2 in Human Lung Cells and Chimeric SARS-CoV Expressing the SARS-CoV-2 RNA Polymerase in Mice. Cell Rep 32, 107940 (2020).

27. R. L. Mackman, H. C. Hui, M. Perron, E. Murakami, C. Palmiotti, G. Lee, K. Stray, L. Zhang, B. Goyal, K. Chun, D. Byun, D. Siegel, S. Simonovich, V. Du Pont, J. Pitts, D. Babusis, A. Vijjapurapu, X. Lu, C. Kim, X. Zhao, J. Chan, B. Ma, D. Lye, A. Vandersteen, S. Wortman, K. T. Barrett, M. Toteva, R. Jordan, R. Subramanian, J. P. Bilello, T. Cihlar, Prodrugs of a 1'-CN-4-Aza-7,9-dideazaadenosine C-Nucleoside Leading to the Discovery of Remdesivir (GS-5734) as a Potent Inhibitor of Respiratory Syncytial Virus with Efficacy in the African Green Monkey Model of RSV. J Med Chem 64, 5001-5017 (2021).

28. Y. J. Hou, K. Okuda, C. E. Edwards, D. R. Martinez, T. Asakura, K. H. Dinnon, 3rd, T. Kato, R. E. Lee, B. L. Yount, T. M. Mascenik, G. Chen, K. N. Olivier, A. Ghio, L. V. Tse, S. R. Leist, L. E. Gralinski, A. Schafer, H. Dang, R. Gilmore, S. Nakano, L. Sun, M. L. Fulcher, A. Livraghi-Butrico, N. I. Nicely, M. Cameron, C. Cameron, D. J. Kelvin, A. de Silva, D. M. Margolis, A. Markmann, L. Bartelt, R. Zumwalt, F. J. Martinez, S. P. Salvatore, A. Borczuk, P. R. Tata, V. Sontake, A. Kimple, I. Jaspers, W. K. O'Neal, S. H. Randell, R. C. Boucher, R. S. Baric, SARS-CoV-2 Reverse Genetics Reveals a Variable Infection Gradient in the Respiratory Tract. Cell 182, 429-446 e414 (2020).

29. X. Xie, A. E. Muruato, X. Zhang, K. G. Lokugamage, C. R. Fontes-Garfias, J. Zou, J. Liu, P. Ren, M. Balakrishnan, T. Cihlar, C. K. Tseng, S. Makino, V. D. Menachery, J. P. Bilello, P. Y. Shi, A nanoluciferase SARS-CoV-2 for rapid neutralization testing and screening of anti-infective drugs for COVID-19. Nat Commun 11, 5214 (2020).

30. S. R. Leist, K. H. Dinnon, 3rd, A. Schäfer, L. V. Tse, K. Okuda, Y. J. Hou, A. West, C. E. Edwards, W. Sanders, E. J. Fritch, K. L. Gully, T. Scobey, A. J. Brown, T. P. Sheahan, N. J. Moorman, R. C. Boucher, L. E. Gralinski, S. A. Montgomery, R. S. Baric, A 
Version 9.4

Mouse-Adapted SARS-CoV-2 Induces Acute Lung Injury and Mortality in Standard Laboratory Mice. Cell 183, 1070-1085.e1012 (2020).

31. R. L. Graham, E. F. Donaldson, R. S. Baric, A decade after SARS: strategies for controlling emerging coronaviruses. Nat Rev Microbiol 11, 836-848 (2013).

32. L. Rosenbaum, Escaping Catch-22 - Overcoming Covid Vaccine Hesitancy. $N$ Engl J Med 384, 1367-1371 (2021).

33. B. Adhikari, P. Y. Cheah, Vaccine hesitancy in the COVID-19 era. Lancet Infect Dis, (2021).

34. Z. Wang, F. Schmidt, Y. Weisblum, F. Muecksch, C. O. Barnes, S. Finkin, D. SchaeferBabajew, M. Cipolla, C. Gaebler, J. A. Lieberman, T. Y. Oliveira, Z. Yang, M. E. Abernathy, K. E. Huey-Tubman, A. Hurley, M. Turroja, K. A. West, K. Gordon, K. G. Millard, V. Ramos, J. Da Silva, J. Xu, R. A. Colbert, R. Patel, J. Dizon, C. UnsonO'Brien, I. Shimeliovich, A. Gazumyan, M. Caskey, P. J. Bjorkman, R. Casellas, T. Hatziioannou, P. D. Bieniasz, M. C. Nussenzweig, mRNA vaccine-elicited antibodies to SARS-CoV-2 and circulating variants. Nature 592, 616-622 (2021).

35. A. J. Brown, J. J. Won, R. L. Graham, K. H. Dinnon, 3rd, A. C. Sims, J. Y. Feng, T. Cihlar, M. R. Denison, R. S. Baric, T. P. Sheahan, Broad spectrum antiviral remdesivir inhibits human endemic and zoonotic deltacoronaviruses with a highly divergent RNA dependent RNA polymerase. Antiviral Res 169, 104541 (2019).

36. W. T. Harvey, A. M. Carabelli, B. Jackson, R. K. Gupta, E. C. Thomson, E. M. Harrison, C. Ludden, R. Reeve, A. Rambaut, C.-G. U. Consortium, S. J. Peacock, D. L. Robertson, SARS-CoV-2 variants, spike mutations and immune escape. Nat Rev Microbiol 19, 409424 (2021).

37. D. C. Montefiori, P. Acharya, SnapShot: SARS-CoV-2 antibodies. Cell Host Microbe 29, 1162-1162 e1161 (2021).

38. R. Martin, J. Li, A. Parvangada, J. Perry, T. Cihlar, H. Mo, D. Porter, E. Svarovskaia, Genetic conservation of SARS-CoV-2 RNA replication complex in globally circulating isolates and recently emerged variants from humans and minks suggests minimal preexisting resistance to remdesivir. Antiviral Res 188, 105033 (2021).

39. Y. Liu, L. M. Yan, L. Wan, T. X. Xiang, A. Le, J. M. Liu, M. Peiris, L. L. M. Poon, W. Zhang, Viral dynamics in mild and severe cases of COVID-19. Lancet Infect Dis 20, 656657 (2020).

40. S. Zheng, J. Fan, F. Yu, B. Feng, B. Lou, Q. Zou, G. Xie, S. Lin, R. Wang, X. Yang, W. Chen, Q. Wang, D. Zhang, Y. Liu, R. Gong, Z. Ma, S. Lu, Y. Xiao, Y. Gu, J. Zhang, H. Yao, K. Xu, X. Lu, G. Wei, J. Zhou, Q. Fang, H. Cai, Y. Qiu, J. Sheng, Y. Chen, T. Liang, Viral load dynamics and disease severity in patients infected with SARS-CoV-2 in Zhejiang province, China, January-March 2020: retrospective cohort study. BMJ 369, m1443 (2020).

41. F. Zhou, T. Yu, R. Du, G. Fan, Y. Liu, Z. Liu, J. Xiang, Y. Wang, B. Song, X. Gu, L. Guan, Y. Wei, H. Li, X. Wu, J. Xu, S. Tu, Y. Zhang, H. Chen, B. Cao, Clinical course and risk factors for mortality of adult inpatients with COVID-19 in Wuhan, China: a retrospective cohort study. Lancet 395, 1054-1062 (2020).

42. X. Lu, L. Wang, S. K. Sakthivel, B. Whitaker, J. Murray, S. Kamili, B. Lynch, L. Malapati, S. A. Burke, J. Harcourt, A. Tamin, N. J. Thornburg, J. M. Villanueva, S. Lindstrom, US CDC Real-Time Reverse Transcription PCR Panel for Detection of Severe Acute Respiratory Syndrome Coronavirus 2. Emerg Infect Dis 26, (2020). 
bioRxiv preprint doi: https://doi.org/10.1101/2021.09.13.460111; this version posted September 17, 2021. The copyright holder for this preprint (which was not certified by peer review) is the author/funder, who has granted bioRxiv a license to display the preprint in perpetuity. It is made available under aCC-BY-NC-ND 4.0 International license.

Version 9.4 
Figure 1

A<smiles>N#C[C@]1(c2ccc3c(N)ncnn23)O[C@H](CO)[C@@H](O)[C@H]1O</smiles>

A549-hACE2

D

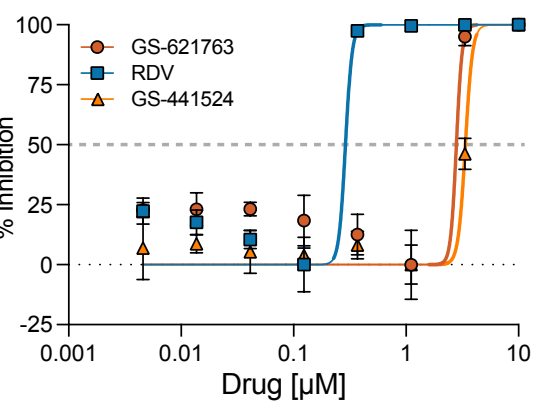

G

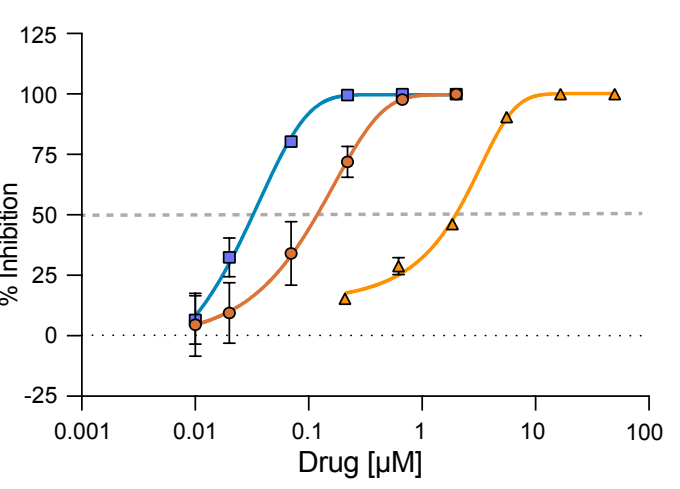

RDV<smiles>CCC(CC)COC(=O)[C@H](C)N[P@](=O)(OC[C@H]1O[C@@](C#N)(c2ccc3c(N)ncnn23)[C@H](O)[C@@H]1O)Oc1ccccc1</smiles>

E

A549-hACE2

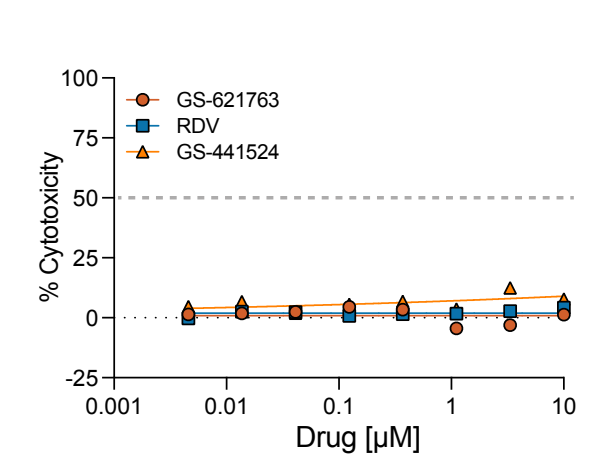

H In vitro potency in human airway cells

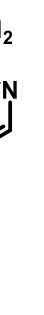

GS-621763<smiles>CC(C)C(=O)OCC1O[C@@](C)(c2ccc3c(N)ncnn23)[C@H](OC(=O)C(C)C)[C@@H]1OC(=O)C(C)C</smiles>

F Antiviral Assay in Primary HAE

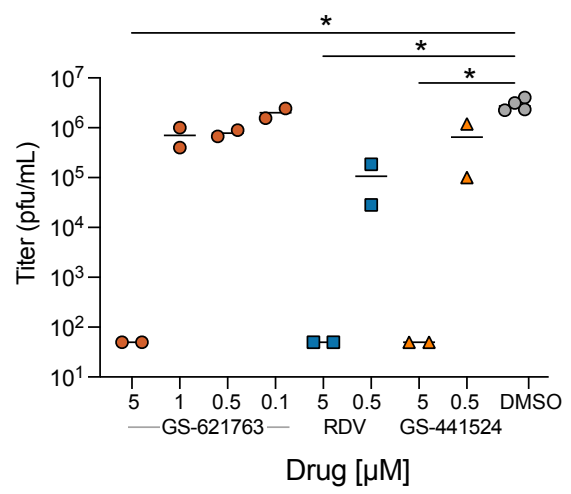

Drug $[\mu \mathrm{M}]$

C

\begin{tabular}{|c|c|c|}
\multicolumn{4}{c}{ Average $\mathrm{EC}_{\mathbf{5 0}}(\mathrm{nM})$} \\
\cline { 2 - 3 } Compound & A549-hACE2 & NHBE \\
\hline GS-621763 & 2801 & $125 \pm 22$ \\
\hline RDV & 293.8 & $37.1 \pm 0.4$ \\
\hline GS-441524 & 3368 & $2454 \pm 63$ \\
\hline
\end{tabular}




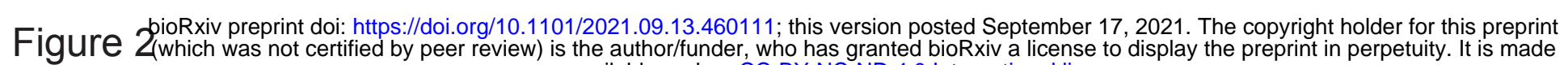

A. Plasma pharmacokinetics

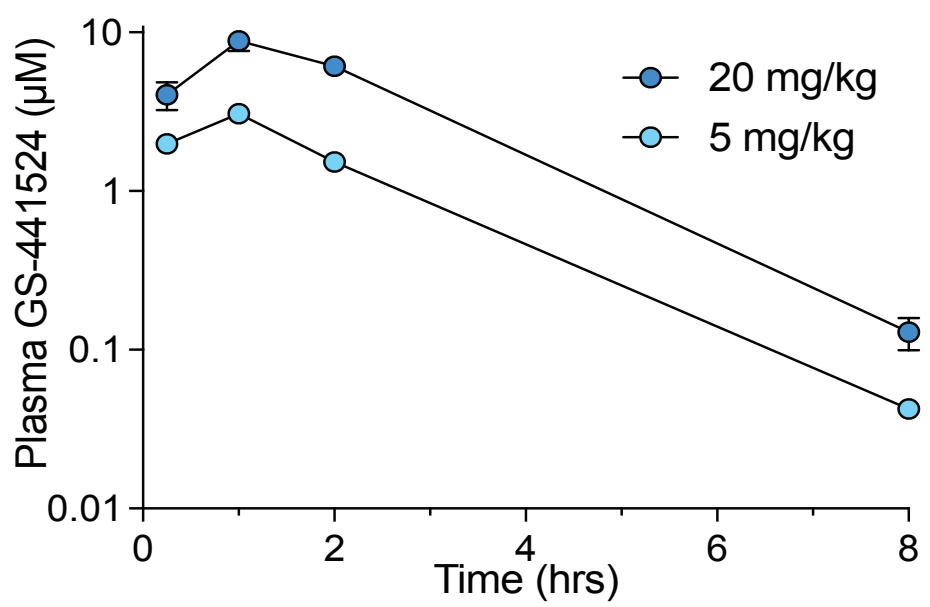

D. Pulmonary Function

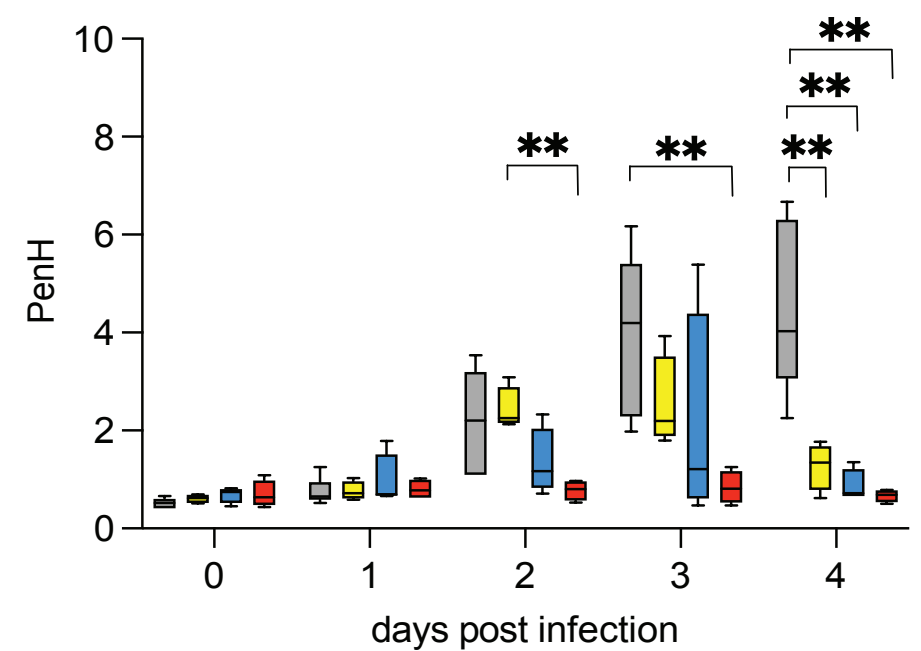

B. Weight loss

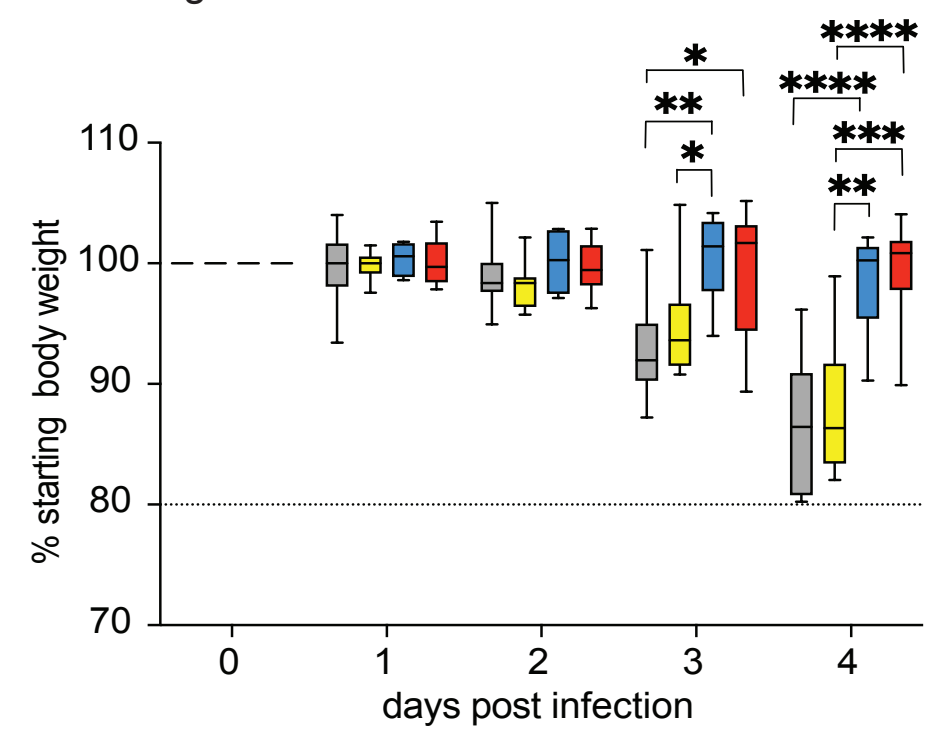

C. Viral Titer Lung $4 \mathrm{dpi}$

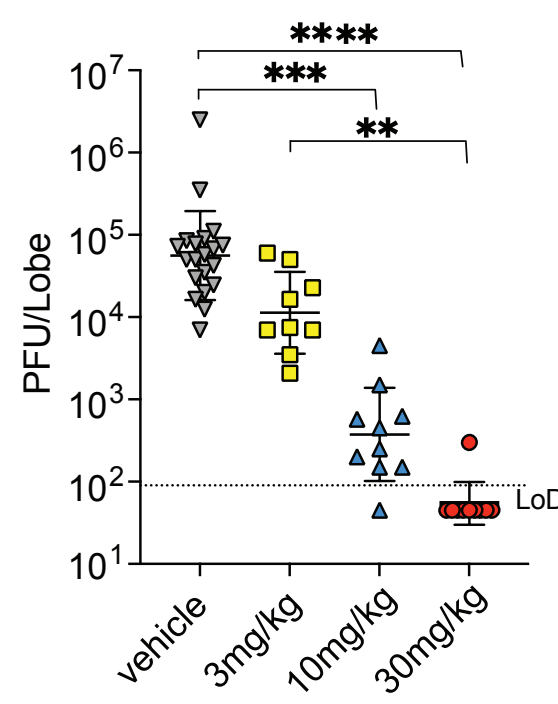

GS-621763
Group/dosage

$\nabla$ vehicle

口 GS-621763; 3mg/kg, BID

$\triangle$ GS-621763; 10mg/kg, BID

O GS-621763; 30mg/kg, BID
E. Congestion Score 4dpi

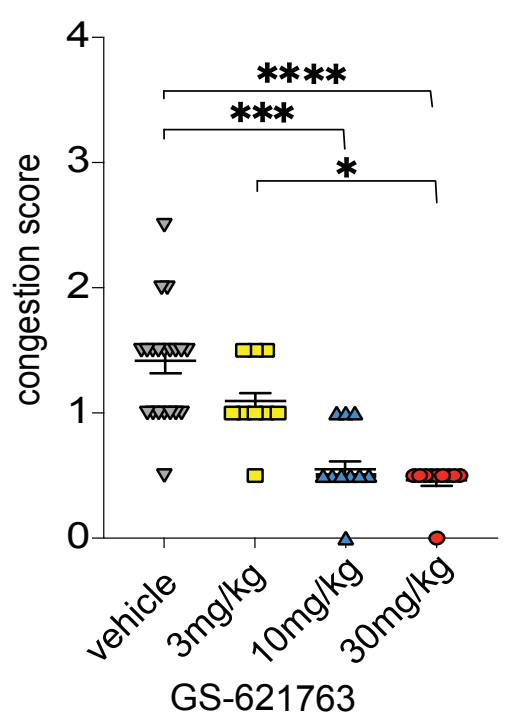

F. ATS Acute Lung Injury 4dpi

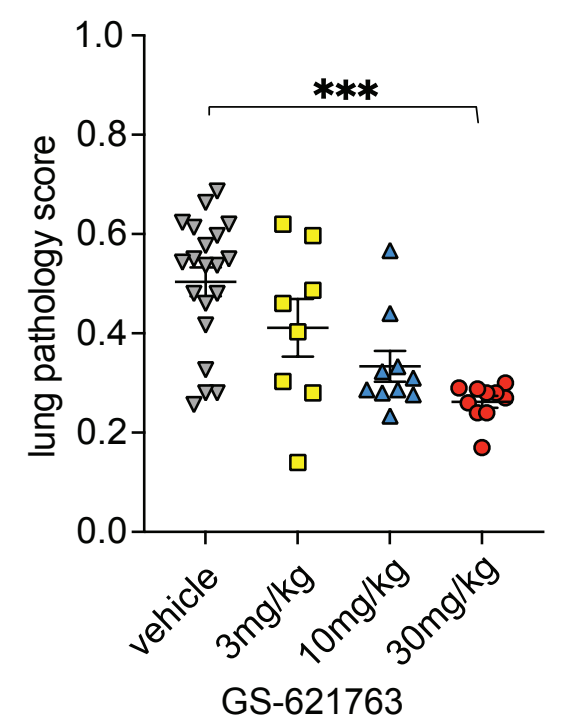

G. Diffuse Alveolar Damage 4dpi

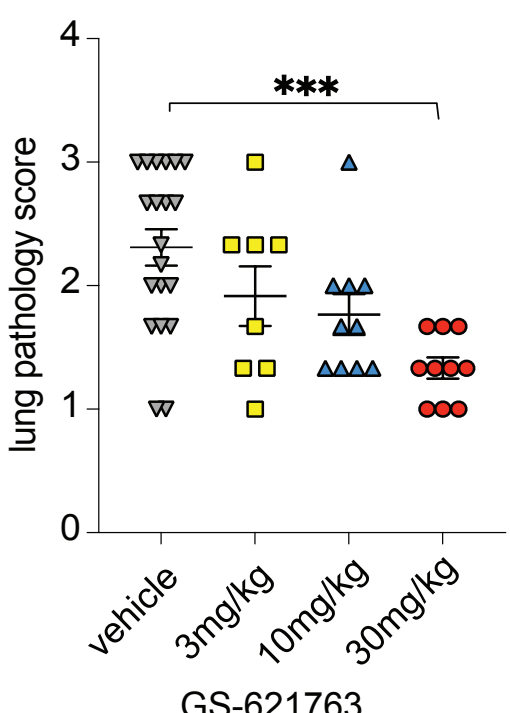

